\title{
Effects of Nitrogen Fertilizer Quantity and Time of Application on Sorghum (Sorghum bicolor (L.) Moench) Production in Lowland Areas of North Shewa, Ethiopia
}

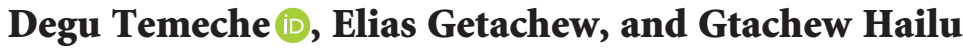 \\ Amhara Regional Agricultural Research Institute, Debre Birhane Agricultural Research Center, P.O. Box 112, \\ Debre Birhane, Ethiopia \\ Correspondence should be addressed to Degu Temeche; temeche12@gmail.com
}

Received 19 July 2021; Accepted 9 October 2021; Published 23 October 2021

Academic Editor: Vera Popovic

Copyright $(92021$ Degu Temeche et al. This is an open access article distributed under the Creative Commons Attribution License, which permits unrestricted use, distribution, and reproduction in any medium, provided the original work is properly cited.

This research was conducted to assess the effect of rates and time of nitrogen fertilizer application on yield and yield components of sorghum in lowland areas of North Shewa. The treatments contained three rates of nitrogen (N) $\left(46,92\right.$, and $\left.138 \mathrm{~kg} \cdot \mathrm{ha}^{-1}\right)$ and three times of $\mathrm{N}$ application ( $1 / 2$ dose at sowing and $1 / 2$ dose at tillering (timing one); $1 / 3$ dose at sowing and $2 / 3$ dose at tillering (timing two); and 1/3 dose at sowing, 1/3 dose at early tillering, and 1/3 dose at tillering (timing three) including one control. Days to $50 \%$ maturity, plant height, head length, head weight, and grain yield were significantly affected by treatment effect, while days to emergency, days to heading, and thousand kernel weight showed nonsignificant effect. The maximum grain yield was 5.060, $5.169,5.836$, and $5.555 \mathrm{t} \cdot \mathrm{ha}^{-1}$ from T2, T5, T8, and T10, respectively, and statistically similar yield was recorded at combination of different rates in two split applications (1/2 dose at sowing and 1/2 dose at tillering). By considering the economic status of the farmers, the applications of $46 \mathrm{~kg} \cdot \mathrm{N} \cdot \mathrm{ha}^{-1}$ in two split doses $(1 / 2$ dose at sowing and $1 / 2$ dose at tillering stage $)$ gave $87,122 \mathrm{Birr}^{-h^{-1}}$ with a MRR of $475.61 \%$, which gave best economic benefit. Therefore, it can be concluded that use of $46 \mathrm{~kg} \cdot \mathrm{N} \cdot \mathrm{ha}{ }^{-1}$ in two split applications ( $1 / 2$ dose at sowing and $1 / 2$ dose at tillering stage) can be recommended for farmers for production of sorghum in the study area and other areas with similar agroecological conditions.

\section{Introduction}

Sorghum (Sorghum bicolor (L.) Moench) is an important cereal crop belonging to the grass family Poaceae [1]. Sorghum is the world's fifth major cereal in terms of production and acreage. It covers an area harvested 18, 28182 ha yield with the production of $52,65,580$ tones [2]. Sorghum is among the most important grain crops in the world including Ethiopia. Because of its multiple purposes and its ability to cope up with unfavorable growing conditions, sorghum will continue to feed the world's increasing populations. Moreover, it will be the crop of the future due to the changing global climatic trends and increase in use of marginal lands for agriculture [3]. Sorghum is widely grown in the high lands, low lands, and semiarid regions of Ethiopia, especially in moisture stressed parts where other crops can least survive [4].
Sorghum is one of the most important cereal crops cultivated in Ethiopia. It is the third important cereal crop next to teff and maize. It is an economically, socially, and culturally important crop grown over a wide range of ecological habitats in the country, in the range of 400-3000 m.a.sl [5]. Sorghum is the single most important cereal in the lowland areas because of its drought tolerance [6].

In Ethiopia, during 2019/20 cropping season, $1,828,182.49$ hectares of land area was covered by sorghum with the average yield productivity of 2.88 tone $\mathrm{ha}^{-1}$ [7]. It is known for its versatility and diversity and is produced over a wide range of agroecological zones. In Amhara region, sorghum was produced on $641,613.53$ hectares of land with an average yield productivity of 2.83 tone $\mathrm{ha}^{-1}$, and in North Shewa Zone of Amhara, sorghum was produced on $133,521.03$ hectares of land in the year 2019/20 cropping season with an average yield of 3.01 tons $\mathrm{ha}^{-1}$ [7]. In the 
study zone, the average yield of sorghum is above the national yield average, but as compared to other countries, the productivity is low. The low productivity of sorghum in developing countries including Ethiopia can be attributed to many biotic and abiotic factors, such as erratic rainfall, disease and pest, and low soil fertility. Low soil moisture or drought can reduce nutrient uptake by roots and induce nutrient shortage by decreasing the diffusion rate of nutrients from soil to root, creating restricted transpiration rates, and impairing active transport and membrane permeability [8]. This indicates that considering soil moisture or rainfall distribution of an area is very important to limit the amount of fertilizer to be applied. Low soil fertility, particularly nitrogen and phosphorus deficiencies, is among the major biophysical constraints affecting agriculture in subSaharan Africa. According to [9], soil fertility depletion in smallholder farmers' holdings is the fundamental biophysical root cause of declining per capita food production.

Nitrogen $(\mathrm{N})$ is commonly the most limiting nutrient factor for crop production in the majority of the world's agricultural areas, and therefore, adoption of good $\mathrm{N}$ management strategies often results in large economic benefits to farmers. Fertilizer $\mathrm{N}$ has contributed more than any other fertilizer towards increasing yield of grain crops, including sorghum. Consequently, $\mathrm{N}$ has become the foremost input in relation to cost and energy requirement in advanced agricultural production systems [10]. Nitrogen is a major input in sorghum production, affecting both yield and quality through influencing those components which have great contribution in increasing grain yield of sorghum [11]. However, in North Shewa, farmers use this fertilizer (nitrogen/urea) as a blanket recommendation, $69 \mathrm{~kg} \cdot \mathrm{N} \cdot \mathrm{ha}^{-1}$, which is the same rate of fertilizer application without considering the soil moisture condition and the fertility status of the soil of an area even though soil moisture content and soil fertility status vary from place to place.

Proper timing of application is the most important factor for $\mathrm{N}$ fertilizer management. Plant use efficiency of $\mathrm{N}$ depends on several factors including application time, rate of $\mathrm{N}$ applied, cultivar, and climatic conditions [12]. The management of $\mathrm{N}$ application time is essential to ensure sustained nutrition at the end of vegetative growth. Therefore, the total amount of $\mathrm{N}$ should be divided into suitable fractions to be applied to best satisfy the requirement of the growing sorghum crop. The aim is to avoid increasing early vegetative growth and to encourage the development of the upper most green parts directly involved in grain formation. Too late application may lead to $\mathrm{N}$ starvation, whereas too early supply may also increase tillering and vegetative growth. However, farmers in North Shewa lowland area apply $\mathrm{N}$ fertilizer in the form of urea at a blanket rate of $69 \mathrm{~kg} \cdot \mathrm{ha}^{-1}$ of N mostly one time at sowing or at a vegetative growth stage for sorghum production. Thus, there is lack of information on the response of sorghum to rate and time of $\mathrm{N}$ fertilizer application in North Shewa Zone. Choosing better $\mathrm{N}$ rate and $\mathrm{N}$ timing, as part of the major solution in this area, is thought to be the major step to minimize the coincidence of drought periods with sensitive crop growth stages that lead to significant yield losses. Therefore, the objective of this study was as follows: (i) To determine the appropriate nitrogen rate and nitrogen timing for maximum yield of sorghum in the lowland of North Shewa

\section{Materials and Methods}

2.1. Description of the Study Area. The experiment was conducted on farmers' fields at three locations, Shewa Robit, Ataye, and Alem Ketema (Jemma valley), under main growing season for two consecutive years (2019-2020). The geographical location of the experimental sites lies between $10^{\circ} 03^{\prime} 55^{\prime \prime} \mathrm{N}$ to $10^{\circ} 17^{\prime} 52^{\prime \prime} \mathrm{N}$ latitude and $38^{\circ} 59^{\prime} 11^{\prime \prime} \mathrm{E}$ to $39^{\circ}$ $54^{\prime} 12^{\prime \prime} \mathrm{E}$ longitude, and altitude ranged from 1365 to 1568 m.a.s.l (Figure 1).

The area has minimum and maximum average annual temperatures of $9.49^{\circ} \mathrm{C}$ and $21.02^{\circ} \mathrm{C}$, respectively. The ten years' average annual rainfall is $1177.14 \mathrm{~mm}$ (data from Kombolcha Meteorological Station (KOMS)) (Figure 2). The major crops grown in the area are sorghum, teff, and mung bean, and from livestock, cattle and goat are dominant for the area. The soil type of the experimental site is clay with a proportion of $35 \%$ sand, $19 \%$ silt, and $46 \%$ clay (Table 1 ). Agroecologically, the research area is lowland to midland.

2.2. Experimental Materials. The sorghum variety used in this experiment was Melkam. The variety is adapted to lowland areas, early maturing type, and widely produced in the study area. Urea $(46 \% \mathrm{~N})$ and triple superphosphate (TSP) with $46 \% \mathrm{P}_{2} \mathrm{O}_{5}$ were used as source of nitrogen and phosphorus, respectively. Soil sampling and analysis: soil samples at a depth of $0-30 \mathrm{~cm}$ were taken from five random spots diagonally across the experimental field using an auger before planting from each experimental site. The collected soil samples were composited. After that, soil organic carbon, total $\mathrm{N}$, soil $\mathrm{pH}$, available $\mathrm{P}$, and texture were analyzed at Debre Birhan Agricultural Research Center Soil Laboratory. The soil $\mathrm{pH}$ was measured in the supernatant suspension of a $1: 2.5$ soil to water ratio using a standard glass electrode $\mathrm{pH}$ meter [13]. The method in [14] was used to determine the organic carbon (\%). Total $\mathrm{N}$ was determined using the Kjeldahl method as described in [15]. Available P (mg. $\mathrm{kg}^{-1}$ ) was determined by employing the method in [16] using ascorbic acid as the reducing agent. The soil particle size distribution was determined using the Bouyoucos hydrometer method [17].

2.3. Treatments and Experimental Design. The experiment was laid out in randomized complete block design (RCBD) with three replications. Improved, early matured sorghum variety (Melkam) was used for the trial. The treatment consists three rates of nitrogen $\left(46,92\right.$, and $\left.138 \mathrm{~kg} \cdot \mathrm{ha}^{-1}\right)$ and three times of $\mathrm{N}$ application including one control. Therefore, we had 10 treatments. Timings of $\mathrm{N}$ application were adjusted as follows: APT1 (1/2 dose at sowing $+1 / 2$ dose at tillering), $\mathrm{APT} 2(1 / 3$ dose at sowing $+2 / 3$ dose at tillering), and APT3 (1/3 dose at sowing $+1 / 3$ dose at early tillering $+1 / 3$ dose at late tillering) were applied as treatments. The gross size of experimental plot was $3.75 \mathrm{~m} \times 3 \mathrm{~m}$ 


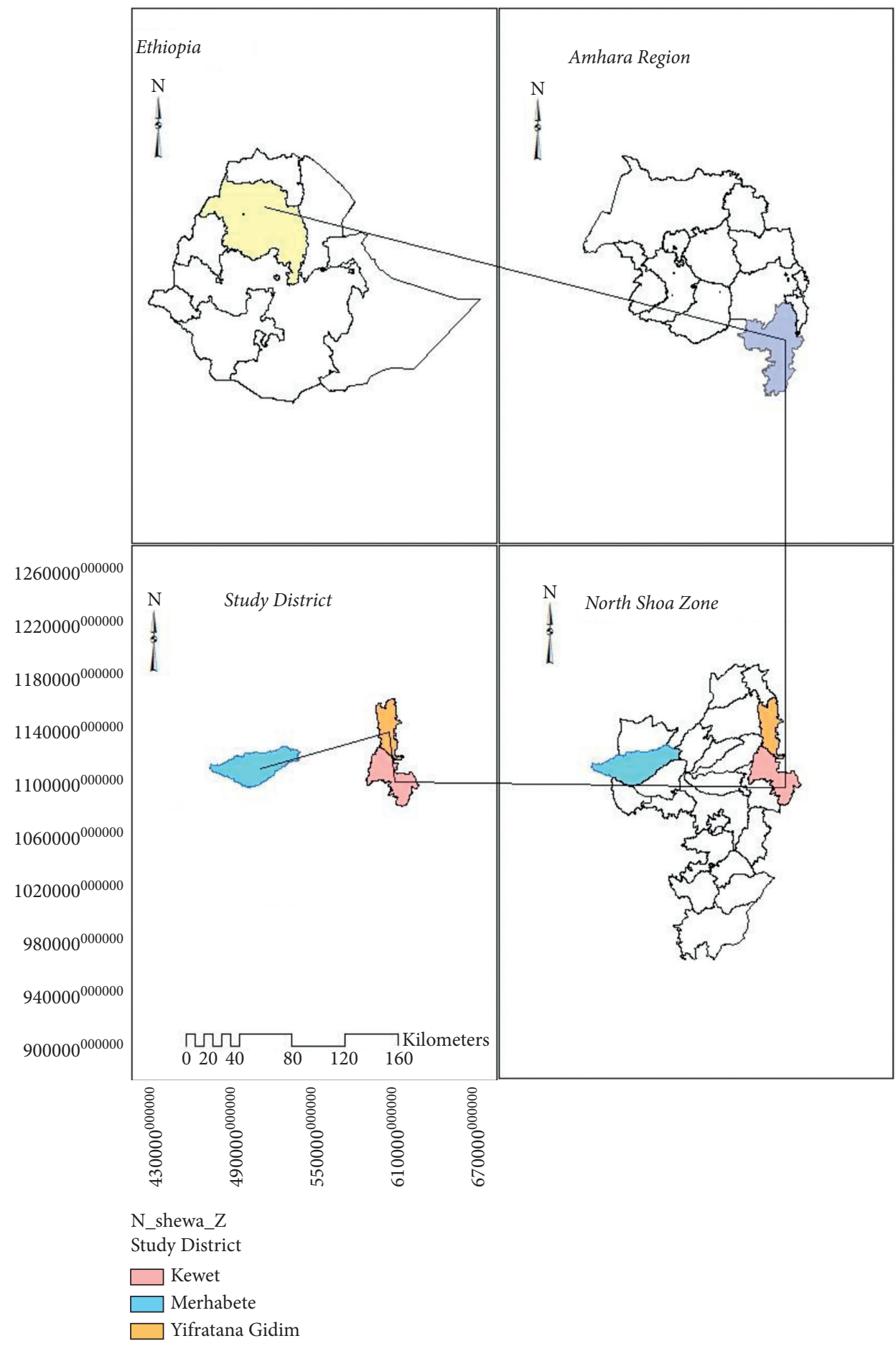

FIgURE 1: Location map of the study district.

$\left(11.25 \mathrm{~m}^{2}\right)$ accommodating five rows of sorghum planted at a spacing of $75 \mathrm{~cm}$ between rows and $15 \mathrm{~cm}$ between plants. The net sampling plot size was $2.25 \mathrm{~m} \times 3 \mathrm{~m}\left(6.75 \mathrm{~m}^{2}\right)$. The seeds were planted at a row spacing of $75 \mathrm{~cm}$ and plant spacing of $15 \mathrm{~cm}$ recommended for sorghum, and this is done by hand in the rows as uniformly as possible and covered with soil manually at a rate of two seeds per hill; after emergence, it was thinned to one seedling per hill. Sorghum was planted on first half of July. Nitrogen fertilizer in the form of urea $(46 \% \mathrm{~N})$ was applied as per treatment. The full dose of $\mathrm{P}$ $\left(60 \mathrm{~kg} \cdot \mathrm{P}_{2} \mathrm{O}_{5} \cdot \mathrm{ha}^{-1}\right)$ was applied uniformly in band application in the form of triple superphosphate (TSP) at planting time of sorghum for all experimental units. Hand weeding was done three times. 


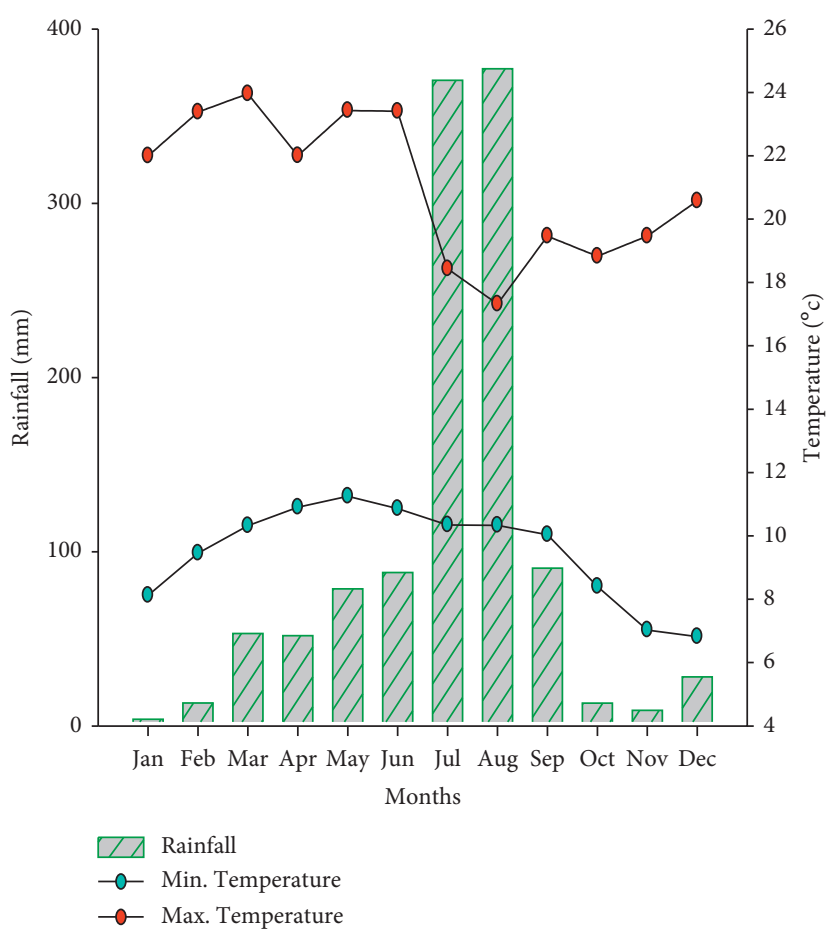

FIGURE 2: Ten years' mean monthly total rainfall and average maximum and minimum temperatures.

TABLE 1: Selected physicochemical properties of the experimental soil before planting.

\begin{tabular}{|c|c|c|c|c|c|c|c|c|}
\hline \multirow{2}{*}{ Soil pH } & \multirow{2}{*}{ \%Organic carbon } & \multirow{2}{*}{ \%Total nitrogen } & \multirow{2}{*}{$\%$ Organic matter } & \multirow{2}{*}{ Available phosphorus } & \multicolumn{3}{|c|}{ Texture } & \multirow{2}{*}{ Texture class } \\
\hline & & & & & Sand & Clay & Silt & \\
\hline 6.63 & 1.68 & 0.14 & 2.89 & 36.55 & 35 & 46 & 19 & Clay \\
\hline
\end{tabular}

\subsection{Data Collection and Measurement}

Days to $50 \%$ emergency: it was recorded as the number of days from planting to the date at which $50 \%$ of the plants emerged.

Days to $50 \%$ heading: it was recorded as the number of days from planting to the date at which $50 \%$ of the plants in a plot produced head.

Days to $50 \%$ maturity: it was recorded on the date at which $50 \%$ of the head per plot reached physiological maturity.

Plant height: it was measured at physiological maturity from the ground level to the tip of head from ten randomly taken plants and was averaged on per plant basis. Head length: it is the length of the head from the node where the first head branches emerge to the tip of the head which was determined from an average of ten randomly taken heads per net plot.

Head weight $(\mathrm{g})$ : samples of ten heads were weighed after harvesting and sun drying to determine weight per head.

Thousand kernels weight (g): it was determined by counting 1000 grains and weighting them on a sensitive balance. The weight was adjusted to $12.5 \%$ moisture level.
Grain yield (kg): it was obtained from all plants of net plot area. It was determined using sensitive balance after the panicles were threshed, cleaned, and sun dried, and the yield was adjusted to $12.5 \%$ moisture level. Then, it was converted to tone ha ${ }^{-1}$ basis.

Data analysis: data collected were subjected to analysis of variance (ANOVA) using the SAS V.9.0 and tested for their significance, and whenever the effects of the treatments were found significant, the means were compared using least significance difference (LSD) test at $5 \%$ level of significance.

The economic analysis was carried out by using the methodology described in [18], in which market prices for inputs at sowing and for outputs at harvesting were used. In this paper, all costs and benefits were calculated in Ethiopian Birr per hectare (ETB.ha ${ }^{-1}$ ) basis. The ideas used in the partial budget analysis were the mean grain yield of each treatment, the gross benefit ha ${ }^{-1}$ (the mean yield for each treatment), and the field price of fertilizers (urea and the time of application costs). Marginal rate of return, which refers to net income obtained by incurring a unit cost of fertilizer and its application, was calculated by dividing the net increase in yield of sorghum due to the application of each fertilizer's rate. Total variable cost was calculated by summing up the costs that vary, including the cost of urea 
TABLE 2: Summary of probability values of combined analysis of variance over environments (year $*$ loc) and treatments $(\mathrm{N}$ rate $* \mathrm{~N}$ timing).

\begin{tabular}{|c|c|c|c|c|c|c|c|c|c|}
\hline \multirow{2}{*}{ Source of variation } & \multirow{2}{*}{$\mathrm{DF}$} & \multicolumn{8}{|c|}{ Probability } \\
\hline & & $\mathrm{DE}$ & $\mathrm{DH}$ & $\mathrm{DM}$ & PHT & PL & HWT & GY & TKW \\
\hline Year & 1 & $<0001$ & $<0001$ & 0.0003 & $<0001$ & 0.585 & $<0001$ & $<0001$ & 0.7231 \\
\hline Loc & 3 & 0.3324 & $<0001$ & 0.4783 & 0.2629 & $<0001$ & $<0001$ & $<0001$ & 0.9154 \\
\hline Rep & 2 & 0.012 & $<0001$ & 0.1241 & 0.9606 & 0.0151 & 0.039 & 0.0031 & 0.2902 \\
\hline Tret & 9 & 0.0369 & 0.7753 & $<0001$ & $<0001$ & 0.0102 & 0.0155 & 0.0007 & 0.0519 \\
\hline Year $*$ loc & 3 & $<0001$ & 0.0171 & $<0001$ & $<0001$ & 0.7666 & $<0001$ & $<0001$ & 0.705 \\
\hline Year $*$ tret & 9 & 0.5803 & 0.3267 & 0.247 & 0.2998 & 0.9935 & 0.9156 & 0.1981 & 0.8894 \\
\hline Loc $*$ tret & 27 & 0.0698 & 0.0842 & 0.6058 & 0.1429 & 0.0836 & 0.0582 & 0.0116 & 0.5568 \\
\hline Year $*$ loc $*$ tret & 27 & 0.0072 & 0.3718 & 0.7329 & 0.002 & 0.0638 & 0.0447 & 0.0023 & 0.8389 \\
\hline $\mathrm{CV}$ & & 13.87 & 3.68 & 3.17 & 3.90 & 5.39 & 20.77 & 16.92 & 6.03 \\
\hline
\end{tabular}

fertilizer (16.20 ETB or $0.41 \$ \cdot \mathrm{kg}^{-1}$ ) and for each time of application cost (4 persons, 200 birr/day or 5 \$ (USD)), and the average open price of sorghum price at Debre Birhan market was Birr 19.66 ETB or $0.5 \$ \cdot \mathrm{kg}^{-1}$ in November 2020 during harvesting time.

Actual grain yield was adjusted downward by $10 \%$ to reflect the difference between the experimental yield and the yield farmers could expect from the same treatment. The dominance analysis procedure, as described in [18], was used to select potentially profitable treatments from the range that was tested. For each pair of ranked treatments, $\%$ marginal rate of return (MRR) was calculated. The treatment with highest net benefit and MRR $>100$ was considered for recommendation.

\section{Results and Discussion}

3.1. Soil Physicochemical Properties of the Experimental Site. Selected physicochemical properties were analyzed for composite soil $(0-30 \mathrm{~cm}$ depth) from the samples collected. The results indicated that texture of the soil in the experimental site was clay (Table 1). The composite soil sample had $2.89 \%$ soil organic matter which is rated as low according to [19] when soils having organic matter value in the range of 2$3 \%$ are considered low. The author of [20] has classified soil total $\mathrm{N}$ content of $0.12-0.25 \%$ as moderate. According to this classification, the soil samples were found to have moderate level of total $\mathrm{N}(0.14 \%)$. The analysis revealed that the available $\mathrm{P}$ of the soil was $36.55 \mathrm{mg} \cdot \mathrm{kg}^{-1}$ (Table 1 ). Indicative ranges of available phosphorus have been established by Cottenie (1980) as $>25 \mathrm{mg} \cdot \mathrm{kg}^{-1}$ of soil (very high). Thus, the soils of the experimental site were considered as very high in available $\mathrm{P}$ content.

3.2. Phenological and Growth Parameters of Sorghum. The analysis result showed that there was nonsignificant difference in days to emergency and days to heading, while days to maturity and plant height and head length showed significant difference between treatments.

Days to $50 \%$ physiological maturity was significantly $(P<0.01)$ affected due to treatments (Table 2$)$. Treatments T9 and T10 statically similar to T8 significantly delayed maturity as compared to other treatments. The maximum days to $50 \%$ maturity (130.50 days) was recorded from
$138 \mathrm{~kg} \cdot \mathrm{N} \cdot \mathrm{ha}^{-1}$ with three-time application, and the minimum (122.17 days) was recorded at a rate of $138 \mathrm{~kg} \cdot \mathrm{N} \cdot \mathrm{ha}{ }^{-1}$ in all nitrogen application times (Table 3). Delay in days to maturity could be due to application of higher level of nitrogen that increased vegetative growth and delayed reproductive period as nitrogen boosts vegetative growth of the plants and make them stay green for long period of time. Similarly, Abrha [12] reported that maturity was more prolonged at the rate of $174 \mathrm{~kg} \cdot \mathrm{N} \cdot \mathrm{ha}^{-1}$.

Plant height: treatments had significant $(P<0.01)$ effect on plant height (Table 2). However, except the control (unfertilized), the others showed statistically similar value. Treatments that have nitrogen increased plant heights than treatments without nitrogen (Table 3$)$. The tallest plant $(145.83 \mathrm{~cm})$ was recorded from T7, and the shortest plant $(124.85 \mathrm{~cm})$ was recorded from T1 (Table 3). Similar result was observed in [21] that there is significant increase in plant height of sorghum when supplied with higher rates of $\mathrm{N}$.

Head length: head length of sorghum was significantly affected $(P<0.05)$ by the treatment effect (Table 2$)$. The highest head length $(28.68 \mathrm{~cm})$ was recorded from T8, and the minimum head length $(26.38 \mathrm{~cm})$ was recorded from T1 (Table 3). The increase in head length with respect to increased $\mathrm{N}$ application rate indicates maximum vegetative growth of the plants under higher $\mathrm{N}$ availability due to the increase in cell elongation as nitrogen is essential for plant growth process.

Head weight: the applied treatment showed significant effect on head weight $(P<0.05)$ (Table 2$)$. The maximum head weight per head $(91.62 \mathrm{~g})$ was obtained from $\mathrm{T} 8$, whereas the minimum head weight $(66.34 \mathrm{~g})$ was recorded from T1. Head weight increased when nitrogen increased with any application time.

Thousand kernel weight: the result indicated that thousand kernel weight showed nonsignificant effect due to treatment difference.

Grain yield: the analysis of variance showed that treatment effect was significant $(P<0.05)$ on grain yield of sorghum (Table 2 ). The highest grain yield $\left(5.836 \mathrm{t} \cdot \mathrm{ha}^{-1}\right)$ was recorded from T8 (application of $138 \mathrm{~kg} \cdot \mathrm{N} \cdot \mathrm{ha}^{-1}$ in two split doses of $1 / 2$ dose at sowing and $1 / 2$ dose at tillering) statistically par with T10, T5, 
TABLE 3: Mean tables for phenological and growth parameters of sorghum as affected by treatments.

\begin{tabular}{|c|c|c|c|c|c|}
\hline Treatment code & $\begin{array}{l}\text { Days to } \\
\text { emergency }\end{array}$ & $\begin{array}{l}\text { Days to } \\
\text { heading }\end{array}$ & $\begin{array}{l}\text { Days to } \\
\text { maturity }\end{array}$ & $\begin{array}{c}\text { Plant } \\
\text { height }(\mathrm{cm})\end{array}$ & $\begin{array}{c}\text { Head } \\
\text { length }(\mathrm{cm})\end{array}$ \\
\hline 1 & 6.33 & 72.83 & $124.25^{\mathrm{cd}}$ & $124.85^{\mathrm{b}}$ & $26.38^{\mathrm{d}}$ \\
\hline 2 & 6.33 & 73.17 & $123.08^{\mathrm{cd}}$ & $142.63^{\mathrm{a}}$ & $27.02^{\mathrm{cd}}$ \\
\hline 3 & 6.08 & 73.08 & $122.17^{\mathrm{d}}$ & $145.21^{\mathrm{a}}$ & $27.20^{\mathrm{b}-\mathrm{d}}$ \\
\hline 4 & 6.25 & 73.25 & $125.42^{\mathrm{bc}}$ & $141.59^{a}$ & $27.00^{\mathrm{cd}}$ \\
\hline 5 & 5.83 & 74.08 & $123.67^{\mathrm{cd}}$ & $145.14^{\mathrm{a}}$ & $27.97^{\mathrm{a}-\mathrm{c}}$ \\
\hline 6 & 5.83 & 72.67 & $123.33^{\mathrm{cd}}$ & $144.83^{\mathrm{a}}$ & $27.81^{\mathrm{a}-\mathrm{c}}$ \\
\hline 7 & 6.00 & 72.75 & $122.25^{\mathrm{cd}}$ & $145.83^{\mathrm{a}}$ & $27.68^{\mathrm{a}-\mathrm{c}}$ \\
\hline 8 & 5.83 & 73.83 & $128.17^{\mathrm{ab}}$ & $145.80^{\mathrm{a}}$ & $28.68^{\mathrm{a}}$ \\
\hline 9 & 5.50 & 74.50 & $129.75^{\mathrm{a}}$ & $142.02^{\mathrm{a}}$ & $27.97^{\mathrm{a}-\mathrm{c}}$ \\
\hline 10 & 6.75 & 73.67 & $130.50^{\mathrm{a}}$ & $143.19^{a}$ & $28.33^{\mathrm{ab}}$ \\
\hline LSD (5\%) & NS & NS & 3.23 & 4.50 & 1.21 \\
\hline Mean & 6.08 & 73.38 & 125.26 & 142.11 & 27.60 \\
\hline $\mathrm{CV}$ & 13.87 & 3.68 & 3.17 & 3.90 & 5.39 \\
\hline
\end{tabular}

LSD = least significant difference; $C V=$ coefficient of variation; $\mathrm{T} 1=$ control with no fertilizer application; $\mathrm{T} 2=46 \mathrm{~kg} \cdot \mathrm{ha}^{-1} \cdot \mathrm{N}$ with $1 / 2$ at sowing and $1 / 2$ at tillering application; $\mathrm{T} 3=46 \mathrm{~kg} \cdot \mathrm{ha}^{-1} \cdot \mathrm{N}$ with $1 / 3$ at sowing and $2 / 3$ at tillering application; $\mathrm{T} 4=46 \mathrm{~kg} \cdot \mathrm{ha}^{-1} \cdot \mathrm{N}$ with $1 / 3$ at sowing, $1 / 3$ at early tillering, and $1 / 3$ at

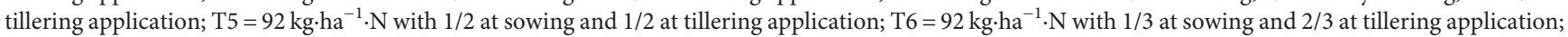
$\mathrm{T} 7=92 \mathrm{~kg} \cdot \mathrm{ha}^{-1} \cdot \mathrm{N}$ with $1 / 3$ at sowing, $1 / 3$ at early tillering, and $1 / 3$ at tillering application; $\mathrm{T} 8=138 \mathrm{~kg} \cdot \mathrm{ha}^{-1} \cdot \mathrm{N}$ with $1 / 2$ at sowing and $1 / 2$ at tillering application; $\mathrm{T} 9=138 \mathrm{~kg} \cdot \mathrm{ha}^{-1} \cdot \mathrm{N}$ with $1 / 3$ at sowing and $2 / 3$ at tillering application; T10 $=138 \mathrm{~kg} \cdot \mathrm{ha}^{-1} \cdot \mathrm{N}$ with $1 / 3$ at sowing, $1 / 3$ at early tillering, and $1 / 3$ at tillering application. Variable followed by the same letters are not significantly different according to the LSD test.

TABLE 4: Mean tables for phenological and growth parameters of sorghum as affected by treatments.

\begin{tabular}{lccc}
\hline Treatment code & $\begin{array}{c}\text { Head } \\
\text { weight }(\mathrm{g})\end{array}$ & $\begin{array}{c}\text { Thousand kernel } \\
\text { weight }(\mathrm{g})\end{array}$ & $\begin{array}{c}\text { Grain yield } \\
\left(\mathrm{t} \cdot \mathrm{ha}^{-1}\right)\end{array}$ \\
\hline 1 & $66.34^{\mathrm{b}}$ & $33.07^{\mathrm{a}}$ & $4.276^{\mathrm{d}}$ \\
2 & $74.92^{\mathrm{b}}$ & $32.57^{\mathrm{a}-\mathrm{c}}$ & $5.060^{\mathrm{a}-\mathrm{c}}$ \\
3 & $74.80^{\mathrm{b}}$ & $32.79^{\mathrm{ab}}$ & $4.764^{\mathrm{b}-\mathrm{d}}$ \\
4 & $66.50^{\mathrm{b}}$ & $32.00^{\mathrm{a}-\mathrm{d}}$ & $4.487^{\mathrm{cd}}$ \\
5 & $76.24^{\mathrm{b}}$ & $31.46^{\mathrm{b}-\mathrm{d}}$ & $5.169^{\mathrm{a}-\mathrm{c}}$ \\
6 & $78.93^{\mathrm{ab}}$ & $30.84^{\mathrm{d}}$ & $4.994^{\mathrm{b}-\mathrm{d}}$ \\
7 & $75.24^{\mathrm{b}}$ & $32.87^{\mathrm{ab}}$ & $4.805^{\mathrm{b}-\mathrm{d}}$ \\
8 & $91.62^{\mathrm{a}}$ & $32.59^{\mathrm{a}-\mathrm{c}}$ & $5.836^{\mathrm{a}}$ \\
9 & $72.79^{\mathrm{b}}$ & $31.24^{\mathrm{cd}}$ & $4.780^{\mathrm{b}-\mathrm{d}}$ \\
10 & $79.02^{\mathrm{ab}}$ & $32.85^{\mathrm{ab}}$ & $5.555^{\mathrm{ab}}$ \\
LSD (5\%) & 13.47 & 1.5 & 7.95 \\
Mean & 75.64 & 32.2 & 4.972 \\
CV & 21.99 & 5.73 & 19.73 \\
\hline
\end{tabular}

LSD = least significant difference; $C V=$ coefficient of variation; $\mathrm{T} 1=$ control with no fertilizer application; $\mathrm{T} 2=46 \mathrm{~kg} \cdot \mathrm{ha}{ }^{-1} \cdot \mathrm{N}$ with $1 / 2$ at sowing and $1 / 2$ at tillering application; $\mathrm{T} 3=46 \mathrm{~kg} \cdot \mathrm{ha}^{-1} \cdot \mathrm{N}$ with $1 / 3$ at sowing and $2 / 3$ at tillering application; $\mathrm{T} 4=46 \mathrm{~kg} \cdot \mathrm{ha} \mathrm{a}^{-1} \cdot \mathrm{N}$ with $1 / 3$ at sowing, $1 / 3$ at early tillering, and $1 / 3$ at tillering application; T5 $=92 \mathrm{~kg} \cdot \mathrm{ha}^{-1} \cdot \mathrm{N}$ with $1 / 2$ at sowing and $1 / 2$ at tillering application; T $6=92 \mathrm{~kg} \mathrm{ha}^{-1} \cdot \mathrm{N}$ with $1 / 3$ at sowing and $1 / 2$ at tillering application; $\mathrm{T} 7=92 \mathrm{~kg} \cdot \mathrm{ha}^{-1} \cdot \mathrm{N}$ with $1 / 3$ at sowing, $1 / 3$ at early tillering, and $1 / 3$ at tillering application; $\mathrm{T} 8=138 \mathrm{~kg} \cdot \mathrm{ha}^{-1} \cdot \mathrm{N}$ with $1 / 2$ at sowing and $1 / 2$ at tillering application; $\mathrm{T} 9=138 \mathrm{~kg} \cdot \mathrm{ha}^{-1} \cdot \mathrm{N}$ with $1 / 3$ at sowing and $2 / 3$ at tillering application; T10 $=138 \mathrm{~kg} \cdot \mathrm{ha}^{-1} \cdot \mathrm{N}$ with $1 / 3$ at sowing, $1 / 3$ at early tillering, and $1 / 3$ at tillering application. Variable followed by the same letters are not significantly different according to the LSD test.

and T2. On the other hand, the lowest grain yield $\left(4.276 \mathrm{t}^{\mathrm{h}} \mathrm{h}^{-1}\right)$ was obtained from T1 $\left(0 \mathrm{~kg} \cdot \mathrm{N} \cdot \mathrm{ha}^{-1}\right)$ (Table 4). Grain yield increased with the increase in the rate of nitrogen with two-time application, statistically par result from $46 \mathrm{~kg} \cdot \mathrm{N} \cdot \mathrm{ha}^{-1}$ up to $138 \mathrm{~kg} \cdot \mathrm{N} \cdot \mathrm{ha}^{-1} \mathrm{ni}-$ trogen (Table 4). Sorghum yield increases with increase in the rate of nitrogen application, but significant difference was observed between control and other rates under two times (1/2 at sowing and $1 / 2$ at tillering). To elaborate the treatment effect, we display Figure 3. In line with this result, Limaux et al. [22] reported that supplying $\mathrm{N}$ in two or three applications is a good recommendation to increase $\mathrm{N}$ use efficiency in sorghum.
Partial budget analysis: the final goal of producers in applying fertilizer is not limited to increasing yield alone, but also to make profit out of it. In the study area, the demand and market price of sorghum are important. Because of this fact, increasing grain yield can increase farmers' income. As indicated in Table 5, the partial budget analysis showed that the highest net benefit of 97,632 Birr.ha $^{-1}$ was obtained in the treatment that received $138 \mathrm{~kg} \cdot \mathrm{N} \cdot \mathrm{ha}^{-1}$ in two split applications $(1 / 2$ dose at sowing and $1 / 2$ dose at tillering stage). However, the lowest net benefit 75,660 Birr.ha $^{-1}$ was obtained from control treatment. The highest marginal rate of return $(842.31 \%)$ was obtained from the plot that applied nitrogen fertilizer 


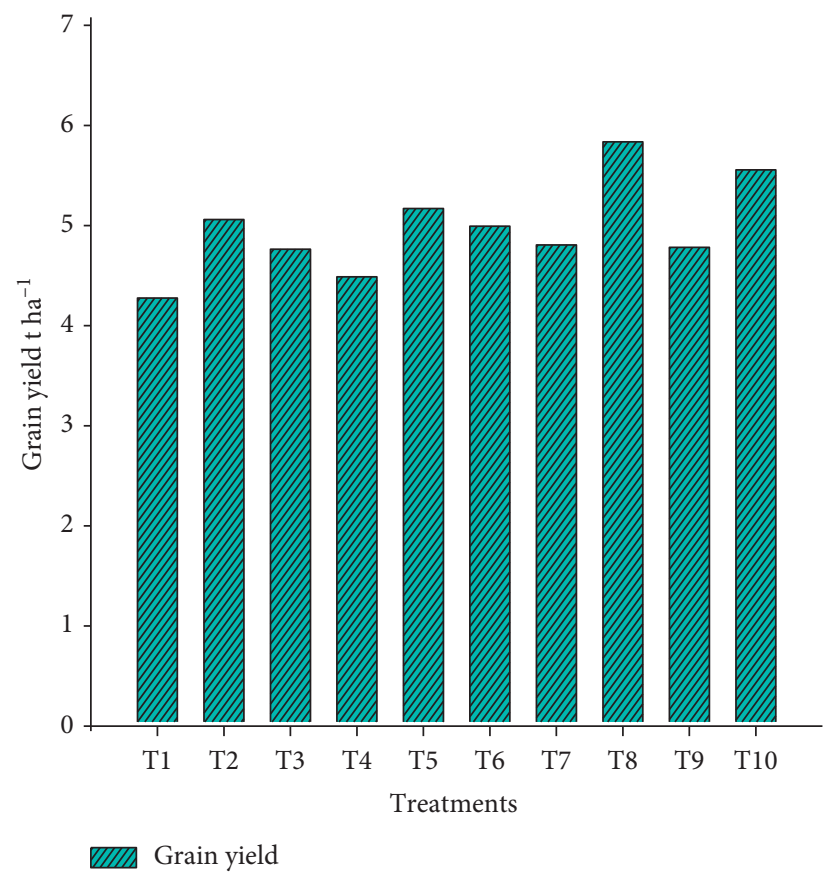

FIGURE 3: The effect of treatments on grain yield. T1 $=$ control with no fertilizer application; $\mathrm{T} 2=46 \mathrm{~kg} \cdot \mathrm{ha}{ }^{-1} \cdot \mathrm{N}$ with $1 / 2$ at sowing and $1 / 2$ at tillering application; $\mathrm{T} 3=46 \mathrm{~kg} \cdot \mathrm{ha}^{-1} \cdot \mathrm{N}$ with $1 / 3$ at sowing and $2 / 3$ at tillering application; $\mathrm{T} 4=46 \mathrm{~kg} \cdot \mathrm{ha}^{-1} \cdot \mathrm{N}$ with $1 / 3$ at sowing, $1 / 3$ at early tillering, and $1 / 3$ at tillering application; $\mathrm{T} 5=92 \mathrm{~kg} \cdot \mathrm{ha}^{-1} \cdot \mathrm{N}$ with $1 / 2$ at sowing and $1 / 2$ at tillering application; $\mathrm{T} 6=92 \mathrm{~kg} \cdot \mathrm{ha}{ }^{-1} \cdot \mathrm{N}$ with $1 / 3$ at sowing and $1 / 2$ at tillering application; $\mathrm{T} 7=92 \mathrm{~kg} \cdot \mathrm{ha}^{-1} \cdot \mathrm{N}$ with $1 / 3$ at sowing, $1 / 3$ at early tillering, and $1 / 3$ at tillering application; $\mathrm{T} 8=138 \mathrm{~kg} \cdot \mathrm{ha}^{-1} \cdot \mathrm{N}$ with $1 / 2$ at sowing and $1 / 2$ at tillering application; $\mathrm{T} 9=138 \mathrm{~kg} \cdot \mathrm{ha}^{-1} \cdot \mathrm{N}$ with $1 / 3$ at sowing and $2 / 3$ at tillering application; $\mathrm{T} 10=138 \mathrm{~kg} \cdot \mathrm{ha}^{-1} \cdot \mathrm{N}$ with $1 / 3$ at sowing, $1 / 3$ at early tillering, and $1 / 3$ at tillering application.

TABLE 5: Partial budget analysis of sorghum yield as influenced by $\mathrm{N}$ fertilizer rates and time of application.

\begin{tabular}{|c|c|c|c|c|c|c|c|c|}
\hline Treatment code & GY & AGY & GFB (ETB $\left.\cdot h^{-1}\right)$ & TVC $\left(\right.$ ETB $\left.\cdot h^{-1}\right)$ & NB $\left(\right.$ ETB $\left.\cdot h^{-1}\right)$ & MC & MNB & MRR\% \\
\hline 1 & 4.276 & 3.848 & 75660 & 0 & 75660 & 0 & 0.00 & \\
\hline 2 & 5.060 & 4.554 & 89532 & 2410 & 87122 & 2410 & 11462.10 & 475.61 \\
\hline 3 & 4.764 & 4.288 & 84294 & 2410 & 81884 & 0 & $\mathrm{D}$ & \\
\hline 4 & 4.487 & 4.038 & 79393 & 2810 & 76583 & 400 & $\mathrm{D}$ & \\
\hline 5 & 5.169 & 4.652 & 91460 & 4020 & 87440 & 1210 & 318.65 & 26.33 \\
\hline 6 & 4.994 & 4.495 & 88364 & 4020 & 84344 & 0 & $\mathrm{D}$ & \\
\hline 7 & 4.805 & 4.325 & 85020 & 4420 & 80600 & 400 & $\mathrm{D}$ & \\
\hline 8 & 5.836 & 5.252 & 103262 & 5630 & 97632 & 1210 & 10191.90 & 842.31 \\
\hline 9 & 4.780 & 4.302 & 84577 & 5630 & 78947 & 0 & $\mathrm{D}$ & \\
\hline 10 & 5.555 & 5.000 & 98290 & 6030 & 92260 & 400 & $\mathrm{D}$ & \\
\hline
\end{tabular}

Treatment code similar with Table 3. GY= grain yield; $\mathrm{AGY}=$ adjusted grain yield; $\mathrm{GFB}=$ gross field benefit; $\mathrm{TVC}=$ total variable cost; $\mathrm{NB}=$ net benefit; $\mathrm{MRR}=$ marginal rate of return; $\mathrm{D}=$ dominated treatments. Market price of sorghum $=19.66 \mathrm{ETB} \cdot \mathrm{kg}^{-1}$; cost of urea $=35 \mathrm{ETB} \cdot \mathrm{kg}^{-1} ;$ labour cost for application of nitrogen $=4$ persons $\mathrm{ha}^{-1}$, each $200 \mathrm{ETB} \cdot \mathrm{day}^{-1}$ for one time application; ETB $=$ Ethiopian birr.

$\left(138 \mathrm{~kg} \mathrm{ha}^{-1}\right)$ in two split applications $(1 / 2$ dose at sowing and $1 / 2$ dose at tillering stage). For treatment to be considered as advisable to farmers, between $50 \%$ and $100 \%$ marginal rate of return (MRR) was the minimum acceptable rate of return [18]. Therefore, $475.61 \%$ was recorded from application of $46 \mathrm{~kg} \cdot \mathrm{N} \cdot \mathrm{ha}^{-1}$ in two split doses $(1 / 2$ dose at sowing and $1 / 2$ dose at tillering stage) with better net benefit, and MRR is profitable and recommended for farmers in lowland areas of North Shewa area and other similar agroecological condition.

\section{Conclusion}

Among taken parameters, days to $50 \%$ maturity, plant height, head length, head weight, and grain yield were significantly affected by treatment effect, while days to emergency, days to heading, and thousand kernel weight showed nonsignificant effect. The maximum grain yield was 5.060, 5.169, 5.836, and 5.555 t.ha ${ }^{-1}$ from T2, T5, T8, and T10, respectively, and statistically similar yield was recorded at combination of different rates in two split applications (1/ 2 dose at sowing and 1/2 dose at tillering). The partial budget 
analysis revealed that combined applications of $138 \mathrm{~kg} \cdot \mathrm{N} \cdot \mathrm{ha}^{-1}$ in two split doses $(1 / 2$ dose at sowing and $1 / 2$ dose at tillering stage) gave the best economic benefit $\left(97,632 \mathrm{Birr} \mathrm{ha}^{-1}\right)$ with a MRR of $842.31 \%$, followed by applications of $46 \mathrm{~kg} \cdot \mathrm{N} \cdot \mathrm{ha}^{-1}$ in two split doses $(1 / 2$ dose at sowing and $1 / 2$ dose at tillering stage), which gave $87,122 \mathrm{Birr}^{-h^{-1}}$ with a MRR of $475.61 \%$. Therefore, it can be concluded that use of $46 \mathrm{~kg} \cdot \mathrm{N} \cdot \mathrm{ha}^{-1}$ in two split applications (1/2 dose at sowing and $1 / 2$ dose at tillering stage) can be recommended for farmers for production of sorghum in the study area and other areas with similar agroecological conditions by considering low-income farmers.

\section{Data Availability}

The data used to support the findings of this study are available from the corresponding author upon request.

\section{Conflicts of Interest}

The authors declare that there are no conflicts of interest regarding the publication of this paper.

\section{Acknowledgments}

The authors would like to thank Amhara Region Agricultural Research Institute, Debre Birhan Research Center, for financial and logistical support.

\section{References}

[1] J. M. Poehlman and D. A. Sleper, Breeding Field Crop, Lowa State University Press, Ames, LO, USA, 4th edition, 1995.

[2] FAO (Food and Agriculture Organization), Fertilizers and Their Use, International Fertilizer Industry Association FAO, Rome, Italy, 4th edition, 2019.

[3] A. H. Paterson, J. E. Bowers, and F. A. Feltus, "Genomics of sorghum, a semi-arid cereal and emerging model for tropical grass genomics," in Genomics of Tropical Crop Plants, H. Paul and R. Moore, Eds., pp. 469-482, Springer Science + Business Media, New York, NY, USA, 2008.

[4] T. Tesso, I. Kapran, C. Grenier et al., "The potential for cropto-wild gene flow in sorghum in Ethiopia and Niger: a geographic survey," Crop Science, vol. 48, no. 4, pp. 1425-1431, 2008.

[5] A. Teshome, D. Patterson, Z. Asfew, J. K. Torrance, and J. T. Arnason, "Changes of Sorghum bicolor landrace diversity and farmers' selection criteria over space and time, Ethiopia," Genetic Resources and Crop Evolution, vol. 54, no. 6, pp. 1219-1233, 2007.

[6] H. Kebede, P. K. Subudhi, D. T. Rosenow, and H. T. Nguyen, "Quantitative trait loci influencing drought tolerance in grain sorghum (Sorghum bicolor L. Moench)," Theoretical and Applied GeneticsTheoretical and Applied Genetics, vol. 103, no. 2, pp. 266-276, 1991.

[7] CSA (Central Statistical Agency), Crop Production Forecast Sample Survey, 2019/20 (2012 E.C.). Report on Area and Crop Production Forecast for Major Crops (For Private Peasant Holding, Meher Season), Statistical Bulletin, Addis Ababa, Ethiopia, 2019.

[8] Y. Assefa, Grain Sorghum in the Hybrid-Era, pp. 1957-2008, Kansas State University, Manhattan, KS, USA, 2010.
[9] P. A. Sanchez, K. D. Shepherd, M. J. Soul, F. M. Place, R. J. Buresh, and A. M. N. Zac, Soil Fertility Replenishment in Africa. Replenishing Soil Fertility Africa", SSSA, Special Publication 51. SSSA, Madison, WI, USA, 1997.

[10] B. M. Yousf, The Response of Some Sorghum Cultivars to Nitrogen Fertilization at Two Sowing Dates, Thesis of MSc, University of Gezira- Faculty of Agricultural Sciences, 1993.

[11] B. Wondimu, Growth, Development and Yield Responses of Sorghum to Water Deficit Stress, Nitrogen Fertilizer, Organic Fertilizer and Planting Density, Doctoral dissertation, University of Pretoria, Pretoria, South Africa, 2004.

[12] K. Abrha, Growth, Productivity, and Nitrogen Use Efficiency of Maize (Zea mays L.) as Influenced by Rate and Time of Nitrogen Fertilizer Application in Haramaya District, Eastern Ethiopia, MSc Thesis, Haramaya University, Haramaya, Ethiopia, 2013.

[13] J. D. Rhoades, In Methods of Soil Analysis, Part 2, A. L. P. Miller and D. R. Keeney, Eds., American Society of Agronomy, Madison, USA, 2nd edition, 1982.

[14] A. Walkley and I. A. Black, "An examination of the degtjareff method for determining soil organic matter, and a proposed modification of the chromic acid titration method," Soil Science, vol. 37, no. 1, pp. 29-38, 1934.

[15] S. R. Olsen, C. W. Cole, F. S. Watanabe, and L. A. Dean, Estimation of Available Phosphorous in Soils by Extraction with Sodium Bicarbonate Circular 939, US. Department of Agriculture, Washington, D.C, WA, USA, 1954.

[16] J. M. Bremner and C. S. Mulvaney, "Methods of soil analysis of total Nitrogen. Part 2-Chemical and microbiological properties," Agronomy, vol. 9, no. 2, pp. 595-624, 1982.

[17] G. J. Bouyoucos, "Hydrometer method improved for making particle size analyses of soils 1," Agronomy Journal, vol. 54, no. 5, pp. 464-465, 1962.

[18] CIMMYT (International Maize and Wheat Improvement Center), From Agronomic Data to Farmer Recommendations: An Economics Training Manual, CIMMYT (International Maize and Wheat Improvement Center), Veracruz, Mexico, 1988.

[19] EthioSIS (Ethiopia Soil Information System), Soil Fertility Status and Fertilizer Recommendation Atlas for Tigray Regional State, EthioSIS (Ethiopia Soil Information System), Tigray, Ethiopia, 2014.

[20] "Soil, plant, water, fertilizer, animal manure and compost analysis," Working Document No. 13, International Livestock Research Center for Africa, Addis Ababa, Ethiopia, 1991.

[21] M. Maral, K. M. Mohammad, A. Ebrahim, K. D. Reza, and R. B. Hamid, "Effects of nitrogen fertilizer and plant density management in corn farming," Journal of Agricultural and Biological Science, vol. 2, pp. 133-137, 2012.

[22] F. Limaux, S. Recous, J.-M. Meynard, and A. Guckert, "Relationship between rate of crop growth at date of fertilizer $\mathrm{N}$ application and fate of fertilizer $\mathrm{N}$ applied to winter wheat," Plant and Soil, vol. 214, no. 1/2, pp. 49-59, 1999. 